\title{
FACE-SAVING AND FACE-THREATENING NEGOTIATION BY LECTURERS: GENDER AND TEACHING EXPERIENCE DIFFERENCES
}

\author{
Sheila Agustina \\ Universitas Muhammadiyah Sidoarjo, Sidoarjo, Indonesia \\ E-mail: agustinasheila27@gmail.com
}

Received: 2021-11-10

Accepted: 2021-12-24

\begin{abstract}
Teachers' use of language was believed to give impact for the success of language learners in one way or another. As some teachers' speech included managing classroom, giving instructions, and providing feedbacks, it is inevitable that a teacher would use the power and make the students uncomfortable. To soften the speech or lessen the impact to the students, a teacher could use some strategies of politeness inside the classroom. Seeing how linguistic politeness manifested by teachers could generally affect the students' esteem, this study aimed at observing face-threatening and face-saving utterances produced by six lecturers during 6 different lessons in a state university. Combining Brown and Levinson's theory of politeness and Yule's concept of face, this study would also contrast the language production by lecturers of different gender and different length of teaching experience to find out if they were correlated. Under the qualitative method, the researcher carried out class observation, recorded the interaction, and transcribed all of the lecturers' utterances. This study revealed that lecturers generally tend to manage more face-saving acts. However, it showed that most face-threatening utterances were generated by male lecturers. It also indicated that lecturers with longer teaching experience produced more face-threatening utterances, and lecturers with shorter teaching experience produced more face-saving utterances. The fact that female lecturers in this study were dominant in negotiating facesaving acts justified women are more polite than men.
\end{abstract}

Keywords: face-saving, face-threatening, politeness, gender, teaching experience

\section{Introduction}

Most people would believe that a competent teacher is the one who is able to provide students the best materials and to teach them using the best method with the best media. In fact, as Brown (2007: 215) states, a teacher's role is also controlling, director managing, facilitating, and resourcing. Considering this matter, the relationship between a teacher and students is, at the first place, determining the success of the student in the classroom. Thus, it is important to note that how the teacher and student are related in the classroom can help the student to actualize him or herself.

Regarding to the teacher-student relationship, language plays important role in class management and the acquisition process of students. It is believed that classroom language also determines the success of teaching and learning activities as well as the medium to enhance students' knowledge acquisition in the classroom (Nunan, 1991, cited in Peng, Xie \& 
Face-Saving and Face-Threatening Negotiation by Lecturers: Gender and Teaching Experience Differences, Sheila Agustina

Cai, 2014: 111). The interaction of teachers and students in classrooms creates a particular discourse where both teachers and students are actively participating in constituting intact communication.

Mugford (2011: 59) rephrases that students' different characteristics acquired from their own culture can be altered through classroom interaction. Therefore, a good classroom interaction is necessary for both teacher and student. A good interaction is able to make students develop their abilities in academic or non-academic sense. It is because, inside the classroom, a teacher does not only provide subject materials but also share moral values that will benefit students outside the classroom. For teachers, a good interaction enables them to build a positive relationship with their students so that the gap between them can be bridged by good communication skills. This is the reason why carrying out effective communication in the classroom is very important and cannot be underestimated. A study by Mantasiah and Yusri (2018) proved that teacher's language politeness has a pivotal role in improving students' academic motivation.

In Indonesia, many researches have been done in relation to the language teacher's competence. Anugerahwati and Saukah (2010) reveal that "English teachers in Indonesia have all the four competences (subject matter, pedagogical, social and personal competences), with the personal competence being the most influential in shaping them as professional and exemplary teachers". It reaffirms that the personal traits and abilities of an individual such as self-awareness, relationship skills and confidence are some important indicators to determine the success of English teachers. The personal competence of a teacher can be seen from the way a teacher manages his or her emotions, understands the students' emotions, and manages relationship with the students.

To manage such relationship, teachers are expected to have a wide concept of etiquette or appropriate behavior and thereby use proper language in the classroom. This properness is mostly associated with the application of linguistic politeness. Grundy (2000: 145) says that "politeness principles have been considered to have wide descriptive power in respect of language use, to be major determinants of linguistic behavior, and to have universal status". Furthermore, to be polite in language, people might use indirect speech acts, address others using respectful tone, or utilize polite utterances such as please, sorry, or thank you (Watts, 2003).

In relation to language usage, Coates (2015) argues that gender influences linguistics manifestation. It infers that language variation used by men is different from language variation used by women. Previously, the issuance of language differences between men and women had actually been explained by Brown and Levinson (1987), stating that "women are universally subordinate to men and therefore more polite". However, when applied to the classroom context, is it true that female teachers are more polite than male teachers? And what other aspect correlates to the classroom politeness?

Considering the phenomenon of language use differences and teacher-student relationship in the classroom, the current researcher is eager to explore these concepts under the study of linguistic politeness. In this study, the researcher will investigate the utterances generated by the lecturers as the subject by analyzing the implementation of face-threatening acts and face-saving acts and learn how differences in gender and teaching experience correlates to the lecturers' choice of language. The study aims at showing the phenomenon to the lecturers as well as the teacher and to raise the awareness of the teachers to use polite language during the classroom interaction. 


\section{Literature Review}

\subsection{Politeness and the concept of 'face'}

The theory of politeness has been long introduced by many linguists. Yule (2010:135) generally says that politeness is same with the action of "being tactful, modest and nice to other people". In the study of politeness, Brown and Levinson's (1987) theory appears as the most famous one. This theory is excessively and frequently used by many researchers who are interested in politeness study. Brown and Levinson's politeness stresses on the concept of 'face', which was first introduced by Goffman in 1967.

According to Brown and Levinson (1987), all members of society have a property, which is best known as 'face'. Brown and Levinson's (1987: 61) definition of face is "the public selfimage that every member wants to claim for himself". It shows the presence of people desire in every society to present himself or herself in a good way within his or her environment. This desire may be beyond people consciousness.

The concept of face contains two different aspects which are described by Brown and Levinson (1987: 61) as positive face and negative face. The positive face refers to human's desire to be well thought, admired, respected, and considered as a good person. On the other side, the negative face refers to human's desire to be free from any burden. Regarding the concept of 'face', Yule (2010: 135) considers politeness "as showing awareness and consideration of another person's face". Thus, every individual is described to have positive and negative face that interlocutors should recognize.

When an individual tries to do and says things which lead to other individual's face losing, Yule (2010: 135) calls it as face-threatening acts (FTAs). Song (2012: 27) defines FTAs as "verbal or non-verbal behaviors that violate the hearer's desire to maintain his/her selfesteem and social respect". Following the aspects of positive and negative face, people may threaten one or both face of the interlocutors. If a speaker impedes his or her interlocutor's desire to be admired, the speaker manages to do positive face-threatening acts. For example, a teacher surely expects himself to be addressed with respectful tone such as "Sir", "Mister", "Professor", etc. However, when his student intentionally calls him by his surname, the teacher will feel disrespected and lose his image as a teacher. The act by the student is then said to be a positive FTA. In opposite, if people interrupt his or her interlocutor's freedom, he or she manages to do negative face-threatening acts. For example, a 14-yearold girl orders her older sister to get her book by saying "Give me that book!". The action by the younger sister causes her older sister's freedom to be disrupted, and it refers to negative FTA.

The fact that it is almost impossible to omit the effect of face-threatening acts, people can get the benefit from speech acts which are less threatening. The effort to minimize face loss hereinafter refers to face-saving acts. Yule (2010: 135) writes that "whenever you say something that lessens the possible threat to another's face, it can be described as a facesaving act".

Face-saving acts also cover both positive and negative face. When an attempt is carried out to minimize the loss of positive face, it is called as positive face-saving act. Otherwise, negative face-saving act is an attempt to minimize the loss of negative face. Yule (2010:135) states that positive face-saving acts concern about interlocutors' solidarity (Let's do this together...; You and I have the same problem, so...). On the contrary, negative face-saving acts deal with the interlocutors' imposition (I'm sorry to bother you...; I know you're busy, but...). 
Face-Saving and Face-Threatening Negotiation by Lecturers: Gender and Teaching Experience Differences, Sheila Agustina

The idea to lessen the face-threatening and minimize face loss is mentioned by Brown and Levinson (1987:68) with term 'politeness strategies'. Following them, Song (2012:27) also states that appropriate politeness strategies are needed to deal with FTA and save hearers' face.

\subsection{Previous Studies}

There have been many studies regarding politeness, face-threatening acts, or facesaving acts in the classroom. Purnomo (2020) in his study about politeness strategies used by teachers in EFL classes revealed that positive politeness becomes the most frequently employed. It implied that the lecturer mostly applied positive politeness in criticizing the students, in order to save the students' face, get closer and give more positive feedback (Heriyawati, Siba and Sulistyo, 2019). In term of the differences on the language usage between male and female, Syafrizal and Putri (2020) who conducted a politeness study on university students showed that women were more respectful than male students in general. Another study of politeness on university students by Nurjanah, Santosa, and Rochsantiningsih (2017) also proved that female students were more polite compared to male students. A newer study of politeness investigating language used by male and female high school students towards their male and female teachers claimed that female students were more polite, but male students showed more polite language to their female teachers rather than to their male teachers (Mulawarman et al., 2021). Next, Mahmud (2019) who also explored the politeness strategies of university students found that politeness expressions used by the students were in the forms of greetings, thanking, addressing terms, apologizing, and fillers. In case of teachers' politeness in classroom, Ningsih, Boeriswati, and Muliastuti (2020) who investigated high school teachers indicated that the teachers can already be categorized politely in speech.

\section{Research Method}

\subsection{Research Design}

This study was under the scope of qualitative study using Discourse Analysis (DA) approach. The qualitative design was used since the data were in the form of words, and the findings would be explained descriptively (Fraenkel and Wallen, 2006). The DA approach was used to explain how the lecturers' utterances are 'used' toward the students in classroom. When the relationship between form and function in verbal communication is investigated, discourse study can be an instrument to describe the relationship (Renkema, 2004:1). In this case, the researcher found whether the utterances generated by the lecturers were indicating face-threatening acts or face-saving acts and correlate them to the lecturers' gender and teaching experience.

\subsection{Research Setting and Participants}

This study was conducted in State University of Malang, and the participants were six lecturers in English Department at the Faculty of Letters. The researcher designated three active male lecturers and three active female lecturers as the research subjects, as a matter of comparison. The lecturers who were designed for the current study were teaching six different courses given in the $3^{\text {rd }}$ and $5^{\text {th }}$ semester. Furthermore, after determining the gender of the lecturers, the researcher also considered how long each lecturer had been teaching in the classroom, and grouped them into shorter teaching experience and longer teaching experience. The grouping was intended to show how the length of teaching 
experiences influence the linguistic manifestations. The consideration for selecting the six courses is based on the type of the course; skill course and content course. For balance, the researcher intentionally chose three skill course classes and three content course classes. The details are presented in following Table 1.

\begin{tabular}{|l|c|c|}
\hline \multicolumn{1}{|c|}{ Course } & Availability & Number of Meeting \\
\hline Intermediate Listening & $3^{\text {rd }}$ semester & 2 \\
\hline Speaking for Formal Interaction & $3^{\text {rd }}$ semester & 2 \\
\hline Basic Analysis of Poetry & $3^{\text {rd }}$ semester & 2 \\
\hline Intermediate English Grammar & $5^{\text {th }}$ semester & 2 \\
\hline Translation & $5^{\text {th }}$ semester & 2 \\
\hline Cross-Cultural Understanding & $5^{\text {th }}$ semester & 2 \\
\hline
\end{tabular}

Table 1. Research Setting

\subsection{Data Collection}

In this study, the data were collected in two main steps. First, the researcher attended the intended classes and recorded the lecturer-student interaction during the teaching and learning process. As the researcher only observed and recorded data without interfering the teacher-student interaction in the classroom, the researcher belonged to non-participant observer. Non-participant observers are those who come to the research site and take notes of the phenomenon happening in the site without being actively involved in the activities (Creswell, 2012:214). Second, the researcher transcribed the lecturers' speech recorded during the classroom observation and eluded all of non-verbal speech such as tone, intonation, or gestures. In this step, the researcher did the data reduction to sort only the utterances containing interpersonal expression such as requesting, ordering, asking, or inviting done by the lecturers toward the students. In short, to collect the complete lecturers' utterances, the researcher used observation procedure using instruments such as field notes, video recording, and transcription. The process of data collection was carried out until the most recent data did not provide any new information. In short, the researcher did not gather more data when the data were considered saturated.

\subsection{Data Analysis}

After two-month class observation, the researcher did the process of data analysis. The researcher sorted and classified the interactive utterances generated by lecturers into two types: the utterances include face-threatening acts and those include face-saving acts. The researcher used Yule's theory on face-threatening and face-saving acts as a ground to identify the utterances. Aside from classifying the data into FTAs and FSAs, the researcher also analyzed the pattern of the occurring FTAs and found out the politeness strategies made by lecturers in generating FSAs. Finally, the researcher drew a conclusion based on the findings related to the study. In concluding the findings, the researcher represented the pattern of FTAs and FSAs in lecturers' utterances and referred them to different groups based on the lecturers' gender and teaching experiences.

\section{Results and Discussion}

\subsection{Face-threatening Utterances}

After analyzing the data, the researcher found that lecturers generated face-threatening utterances less frequent than face-saving utterances. It was shown by the occurrence of 168 face-threatening utterances compared to of 379 face-saving utterances in twelve-meeting 
Face-Saving and Face-Threatening Negotiation by Lecturers: Gender and Teaching Experience Differences, Sheila Agustina

observation. It indicates that the practices of face-threatening acts were not much and did not take the most part in teacher-student interaction. It violates a study by Senowarsito (2013), who claimed that bald on-record strategy or face-threatening was frequent to use inside the classroom. Despite the unpopular use, among all of the face-threatening utterances, the instructional speech is the most identifiable speech acts in classroom language. It explains that lecturers may manage the classrooms by delivering necessary commands to the students.

Furthermore, among 168 face-threatening utterances, there were 21 utterances indicate positive face-threatening acts and 149 utterances indicate negative face-threatening acts. The huge gap between negotiating positive and negative face-threats shows that expressing damage to the students' freedom is somewhat more usual in the classroom. The negative face-threatening utterances found during the observation are all in the forms of direct instructions.

After observing and analyzing the subject and the data, the researcher found a difference in generating face-threatening utterances between male and female lecturers. The following Table 2 describes numbers of how male lecturers were more dominant in generating face-threatening utterances.

\begin{tabular}{|c|c|c|c|}
\hline & $\begin{array}{c}\text { Positive Face-threatening } \\
\text { Utterances }\end{array}$ & $\begin{array}{c}\text { Negative Face-threatening } \\
\text { Utterances }\end{array}$ & Total \\
\hline Female & 14 & 61 & 75 \\
\hline Male & 7 & 88 & 95 \\
\hline
\end{tabular}

Table 2. Gender Differences in Generating Face-threatening Utterances

Aside from gender, the researcher also tried to examine the factor of teaching experience to see if there is a significant difference between a group of lecturers with longer teaching experience and a group of lecturers with shorter teaching experience. The result shows that lecturers with longer teaching experience tended to generate face-threatening utterance more frequent than the other group (Table 3).

\begin{tabular}{|c|c|c|c|}
\hline & $\begin{array}{c}\text { Positive Face-threatening } \\
\text { Utterances }\end{array}$ & $\begin{array}{c}\text { Negative Face- } \\
\text { threatening Utterances }\end{array}$ & Total \\
\hline $\begin{array}{c}\text { Longer teaching } \\
\text { experience }\end{array}$ & 4 & 94 & 98 \\
\hline $\begin{array}{c}\text { Shorter teaching } \\
\text { experience }\end{array}$ & 17 & 55 & 72 \\
\hline
\end{tabular}

Table 3. Teaching Experience Differences in Generating Face-threatening Utterances

\subsection{Face-saving Utterances}

For the face-saving practices in classroom, the researcher found various uses of facesaving strategies. The researcher noted the use of both positive and negative politeness strategies to lessen the negative effect of face-threatening utterances for students. From the positive face-saving view, the lecturers made use of eleven different strategies: Notice/attend to $H$, Exaggerate, Use in-group identity markers, Seek agreement, Avoid agreement, Joke, Offer/promise, Include both $S$ and $H$ in the activity, Assume or assert reciprocity, and Give gifts to $H$. Among these strategies, most lecturers tended to use seek agreement strategy to appreciate the positive face of the students.

As for the negative face-saving view, the lecturers made use of six different strategies: be conventionally indirect, question/hedge, minimize the imposition, give deference, 
apologize, and impersonalize $\mathrm{S}$ and $\mathrm{H}$. Among these six strategies, most lecturers tended to use question/hedge strategy to save the negative face of the students.

Noticing how positive politeness strategies was widely used in the classroom, it is unexpected that, in fact, the utterances which indicate negative politeness strategies were in greater quantities. It was because the lecturers tended to deliver indirect instructions inside the classroom. Therefore, the number of using negative politeness strategies was greater than positive politeness strategies. Among 379 face-saving utterances, 248 were found to be the negative face-savings or negative politeness.

In analyzing face-saving negotiation, the researcher found out that female lecturers generated face-saving utterances more frequently than male lecturers. Although male lecturers also generated more face-saving utterances than face-threatening in one session of a classroom, but the proportion was not as distinct as those generated by female lecturers in one session of a classroom. The numbers of distinction are shown below in Table 4 .

\begin{tabular}{|l|c|c|c|}
\hline & $\begin{array}{c}\text { Positive Face-saving } \\
\text { Utterances }\end{array}$ & $\begin{array}{c}\text { Negative Face-saving } \\
\text { Utterances }\end{array}$ & Total \\
\hline Female & 113 & 181 & 294 \\
\hline Male & 18 & 67 & 85 \\
\hline
\end{tabular}

Table 4. Gender Differences in Generating Face-saving Utterances

In regard to the teaching experiences, the following data (Table 5) tell that lecturers with shorter teaching experience tended to negotiate face-saving utterances more than lecturers with longer teaching experience inside the classroom.

\begin{tabular}{|c|c|c|c|}
\hline & $\begin{array}{c}\text { Positive Face-saving } \\
\text { Utterances }\end{array}$ & $\begin{array}{c}\text { Negative Face-saving } \\
\text { Utterances }\end{array}$ & Total \\
\hline $\begin{array}{c}\text { Longer teaching } \\
\text { experience }\end{array}$ & 26 & 49 & 75 \\
\hline $\begin{array}{c}\text { Shorter teaching } \\
\text { experience }\end{array}$ & 105 & 199 & 304 \\
\hline
\end{tabular}

Table 5. Teaching Experience Differences in Generating Face-saving Utterances

\subsection{Politeness Strategies Utilized by Four Different Groups}

The previous explanation says that female lecturers generated face-saving utterances more frequently than male lecturers. However, the variety of face-saving utterances generated by female lecturers was much smaller than those generated by male lecturers. It shows that male lecturers tended to apply various strategies in saving students' face inside the classroom rather than female lecturers did. Similar research conducted by Arriyani (2017) on politeness applied by a male and a female friend confirmed that the female friend talked more confident and did not use fillers or hedges, while the male friend talked nicely and use many fillers or hedges. It shows that men may not be more polite than women, but men know and use more politeness variation to lessen the impact of their speech.

Comparably, although it is said that a group of lecturers with shorter teaching experience tended to negotiate face-saving utterances more than the other group, the data convincingly pinpoint that the other group is more varied in using different strategies of politeness. Instead, the group of lecturers with longer teaching experience was the most creative group in utilizing both positive and negative politeness strategies. The following Table 6 describes its details. 
Face-Saving and Face-Threatening Negotiation by Lecturers: Gender and Teaching Experience Differences, Sheila Agustina

\begin{tabular}{|c|c|c|c|c|c|}
\hline \multirow{3}{*}{\multicolumn{2}{|c|}{ Politeness Strategies }} & \multicolumn{4}{|c|}{ Influencing Factors } \\
\hline & & \multicolumn{2}{|c|}{ Gender } & \multicolumn{2}{|c|}{$\begin{array}{c}\text { Teaching } \\
\text { Experience }\end{array}$} \\
\hline & & \multirow{2}{*}{$\frac{\text { Male }}{\mathrm{V}}$} & \multirow[t]{2}{*}{ Female } & \multirow{2}{*}{$\frac{\text { Longer }}{\mathrm{V}}$} & \multirow[t]{2}{*}{ Shorter } \\
\hline \multirow{11}{*}{$\begin{array}{l}\text { Positive } \\
\text { Politeness }\end{array}$} & Notice, attend to $\mathrm{H}$ & & & & \\
\hline & Exaggerate & $\mathrm{V}$ & & $\mathrm{V}$ & \\
\hline & Use in-group identity markers & $\mathrm{V}$ & & $\sqrt{ }$ & \\
\hline & Seek agreement & $\mathrm{V}$ & $\mathrm{V}$ & $\mathrm{V}$ & $\mathrm{V}$ \\
\hline & Avoid disagreement & $\sqrt{ }$ & $\sqrt{ }$ & $\mathrm{V}$ & $\sqrt{ }$ \\
\hline & Joke & $\mathrm{V}$ & & $\sqrt{ }$ & \\
\hline & $\begin{array}{l}\text { Assert or presuppose S's knowledge } \\
\text { of and concern for H's wants }\end{array}$ & $\sqrt{ }$ & & $\mathrm{V}$ & \\
\hline & Offer, promise & $\mathrm{V}$ & $\mathrm{V}$ & $\mathrm{V}$ & $\mathrm{V}$ \\
\hline & Include both $\mathrm{S}$ and $\mathrm{H}$ in the activity & & $\mathrm{V}$ & $\mathrm{V}$ & $\mathrm{V}$ \\
\hline & Assume or assert reciprocity & $\mathrm{V}$ & & $\mathrm{V}$ & \\
\hline & Give gifts to $\mathrm{H}$ & $\sqrt{ }$ & $\mathrm{V}$ & $\mathrm{V}$ & $\mathrm{V}$ \\
\hline \multirow{6}{*}{$\begin{array}{l}\text { Negative } \\
\text { Politeness }\end{array}$} & Be conventionally indirect & $\mathrm{V}$ & $\mathrm{V}$ & $\mathrm{V}$ & $\mathrm{V}$ \\
\hline & Question, hedge & $\mathrm{V}$ & $\mathrm{V}$ & $\mathrm{V}$ & $\mathrm{V}$ \\
\hline & Minimize the imposition & $\sqrt{ }$ & $\mathrm{V}$ & $\mathrm{V}$ & $\mathrm{V}$ \\
\hline & Give deference & $\mathrm{V}$ & $\mathrm{V}$ & $\mathrm{V}$ & $\mathrm{V}$ \\
\hline & Apologize & $\sqrt{ }$ & & $\sqrt{ }$ & \\
\hline & Impersonalize $\mathrm{S}$ and $\mathrm{H}$ & $\mathrm{V}$ & & $\mathrm{V}$ & \\
\hline \multicolumn{2}{|l|}{ Total } & 16 & 9 & 17 & 9 \\
\hline
\end{tabular}

Table 6. Politeness Strategies Utilized by Four Different Groups

In addition to the table above, male lecturers apparently use jokes more often to soften their speech and make the class atmosphere livelier, compared to the female lecturers. Sholikhatin and Indah (2019) who conducted a study of politeness in Instagram also stated that the male's comments in Instagram tend to employ the strategy of joking about putting the hearer at ease.

\section{Conclusion}

From the findings, it can be concluded that the practices of face-threatening acts performed by lecturers were not much and did not take the most part in teacher-student interaction. In contrast, the use of face-saving strategies was more various. Furthermore, the researcher found out that female lecturers generated face-saving utterances more frequently than male lecturers. However, male lecturers seem to employ more various politeness strategies than the female group. It reaffirms that language and gender are related, and that patterns of differences in language use between men and women can be observed (Ambarita and Mulyadi, 2020). Likewise, group of lecturers with longer teaching experience was also identified to use more various politeness strategies than lecturers with shorter teaching experience.

The findings of this study are expected to provide remarkable inputs for linguistic and pedagogical sciences and to contribute to the intact development in wider society. More specifically, this study is expected to give benefits for the EFL teachers or lecturers, both theoretically and practically. Theoretically, this current study extends the importance of 
pragmatic awareness for lecturers who teach English as Foreign Language. It will broaden the pragmatic knowledge of EFL teacher, particularly in using politeness in English as a foreign language. Practically, the current study is beneficial for a reference to teach pragmatics issues around the classroom environment, especially politeness.

In addition, this study managed to describe some possible expressions that are frequently generated by lecturers implying threatening acts which may impose the students' esteem. Thus, EFL teachers and lecturers should be aware of using such expressions and should find more polite expressions to deliver the instructions. Moreover, it suggests EFL teachers and lecturers to exercise power without negating students' face, as well as to construct comfortable learning atmosphere and to avoid disadvantageous situation in the classroom.

However, due to the limitations of the study, the results were not quite able to represent the generalization. Thus, it is suggested for future researchers who are willing to conduct the similar research to include a larger amount and variety of data so that generalization can be made more reliable. It is also suggested for further studies to consider non-verbal expressions such as tone, mimics, and gestures to see how those expressions complementing the utterances generated by lecturers. The future studies are also expected to manage more research subjects, in this case the lecturers, with more various backgrounds for comparison to figure out how far actually the different background of the interlocutors can affect their language. Thereby, the findings can provide the readers a lot of useful knowledge in understanding the classroom discourse.

\section{References}

Ambarita, R. \& Mulyadi. (2020). Gender and language politeness. European Journal of Applied Linguistics Studies, 2(2), 19-29.

Anugerahwati, M. \& Saukah, A. (2010). Professional competence of English teachers in Indonesia: A profile of exemplary teachers. Indonesian Journal of English Language Teaching, 6(2), 47-59. Retrieved from http://ojs.atmajaya.ac.id/index.php/ijelt/article/view/170

Arriyani, N. (2017). Genderlect affecting on politeness strategies and language. English Community Journal, 1(1), 1-6. Retrieved from https://doi.org/10.32502/ecj.v1i1.645

Brown, H. D. (2007). Teaching by Principles: An Interactive Approach to Language Pedagogy. New York: Pearson Education.

Brown, P. \& Levinson, S. (1987). Politeness: Some Universals in Language Usage. Cambridge: Cambridge University.

Creswell, J. W. (2012). Educational Research: Planning, Conducting and Evaluating Quantitative and Qualitative Research. Boston: Pearson.

Coates, J. (2015). Women, men and language: A sociolinguistic account of gender differences in language. Routledge.

Fraenkel, J. R. \& Wallen, N. E. (2006). How to Design and Evaluate Research in Education. New York City: McGraw-Hill.

Grundy, P. (2000). Doing Pragmatics. London: Arnold.

Heriyawati, D. F., Siba, S. Y., \& Sulistyo, T. (2019). Lecturers' politeness strategies in EFL classroom with multicultural background. LITERA, 18(3), 447-464. Retrieved from https://doi.org/10.21831/Itr.v18i3.26494 
Face-Saving and Face-Threatening Negotiation by Lecturers: Gender and Teaching Experience Differences, Sheila Agustina

Mahmud, M. (2019). The use of politeness strategies in the classroom context by English university students. Indonesian Journal of Applied Linguistics, 8(3), 597-606. Retrieved from https://doi.org/10.17509/ijal.v8i3.15258

Mantasiah \& Yusri. (2018). The Influence of Teacher's Language Politeness in Improving Student's Academic Motivation. Advances in Social Science, Education and Humanities Research, Proceedings of the 8th International Conference of Asian Association of Indigenous and Cultural Psychology (ICAAIP 2017). Retrieved from https://doi.org/10.2991/icaaip-17.2018.45

Mugford, G. (2011). That's Not Very Polite! Discursive Struggle and Situated Politeness in the Mexican English-language Classroom. In B. L Davies, M. Haugh \& A. J. Merrison (Eds), Situated Politeness (pp.53-72). London: Continuum International.

Mulawarman, W. G., Hudiyono, Y., Andri, \& Ningsi, H. W. (2021). Gender representation and language politeness in speech acts: A pragmatic study. Masyarakat, Kebudayaan dan Politik, 34(3), 329-339. Retrieved from http://dx.doi.org/10.20473/mkp.V34I32021.329-339

Ningsih, R., Boeriswati, E., \& Muliastuti, L. (2020). Language politeness of students and teachers: an ethnographic study. Getsempena English Education Journal, 7(1), 159169. Retrieved from https://doi.org/10.46244/geej.v7i1.1063

Nurjanah, O. W., Santosa, R., \& Rochsantiningsih. (2017). Male and Female Student's Linguistic Politeness in Speaking Classroom. IJPTE 1(2), 147-154. Retrieved from https://doi.org/10.20961/ijpte.v1i2.14510

Peng, L., Xie, F. \& Cai, L. (2014). A case study of college teacher's politeness strategy in EFL classroom. Theory and Practice in Language Studies, 4(1), 110-115. Retrieved from http://ojs.academypublisher.com/index.php/tpls/article/view/tpls0401110115

Purnomo, W. A. (2020). Politeness strategies in teacher-student interaction in EFL classes. Language-Edu, 9(1). Retrieved from http://riset.unisma.ac.id/index.php/LANG/article/view/5060

Renkema, J. (2004). Introduction to Discourse Studies. Amsterdam: John Benjamins.

Senowarsito. (2013). Politeness strategies in teacher-student interaction in an EFL classroom Context. TEFLIN Journal, 24(1), 82-96, Retrieved from https://teflin.org/index.php/teflin/article/viewArticle/316

Sholikhatin, A. D. \& Indah, R. N. (2019). Gender and politeness on Instagram. LingTera, 6(1), 73-82. Retrieved from https://doi.org/10.21831/It.v6i1.26058

Song, S. 2012. Politeness and Culture in Second Language Acquisition. Hampshire: Palgrave Macmillan.

Syafrizal, S., \& Putri, F. S. (2020). A linguistic politeness: an analysis of gender differences in speaking classroom. English Education: Journal of English Teaching and Research, 5(2), 169-178. Retrieved from https://doi.org/10.29407/jetar.v5i2.14436

Watts, R. J. (2003). Politeness: Key Topics in Sociolinguistics. Cambridge: Cambridge University.

Yule, G. (2010). The Study of Language. Cambridge: Cambridge University. 